\title{
The Effect of Entrepreneurial Behavior and Organizational Innovation on MSMEs Performance
}

\author{
Oyong Lisa *)
}

\begin{abstract}
Performance is a reflection of the organization's ability to manage and allocate its resources. This study aims to analyze the influence of entrepreneurial behavior and organizational innovation simultaneously and partially on the performance of MSMEs organization in Lumajang Regency, as well as to analyze the dominant variable affecting organizational performance. The sample in this research is 40 MSMEs with questionnaire as the data collection method. The analysis technique used in this research is multiple regression analysis. The result of the analysis shows that entrepreneurship behavior and organizational innovation influence simultaneously and partially influence organizational performance. Organizational innovation has a dominant influence on organizational performance.
\end{abstract}

Keywords: Entrepreneurship Behavior; Organizational Innovation; Organizational Performance; MSME

\section{INTRODUCTION}

\subsection{Research Background}

Organizational performance is a very important end of all organizational activities because it can be used to evaluate the level of ability and the success of the work process carried out by the organization whether it is in line with expectations or not. Performance is a reflection of the organization's ability to manage and allocate its resources. Micro, Small and Medium Enterprises (MSMEs) are believed to provide support in development and economic growth in a country, not only in developing countries but also in developed countries. The micro, small and medium enterprises sector is one form of an alternative strategy to support economic development in the long run in which they run several programs such as community empowerment and poverty reduction programs based on the empowerment of MSMEs through job creation carried out both by the central government and regional governments. The facts show that the employment opportunities created by MSMEs are bigger than those of large business groups.

MSMEs have a significant influence on the number of business unit growth and the availability of jobs but have several problems like the slow growth of the MSMEs economy to contribute to the value of the gross domestic product, investment, and especially the value of total exports. This makes UMKM the spearhead of National economic growth expected to be able to compete in the global era, especially entering the era of ASEAN economic integration as a stable and prosperous economic region.

Competition in business is natural and will face many challenges in winning a business competition, one of which is by entrepreneurial behavior. Fadiati (2011), stated that entrepreneurial behavior is the result of a work that relies on concepts and theories, not because of the nature of one's personality or based on intuition. So according to this theory, entrepreneurship can be learned and mastered systematically and planned. The results of the study by Adinoto (2010) stated that entrepreneurial behavior does not affect performance. According to Sumantri (2011), entrepreneurial behavior patterns are reflected in entrepreneurial behavior and abilities. This can be seen in the entrepreneurial behavior of MSME entrepreneurs, including personalities that can be 
seen and observed in terms of creativity, self-discipline, self-confidence, courage to face risks, strong drive and willingness, relationships that can be seen from indicators of interpersonal communication and relationships, entrepreneurial leadership and management, marketing which can be seen from the ability to determine products and prices, inventory, and promotions. Expertise in managing is manifested in the form of goal setting, planning, scheduling, and personal arrangements.

In addition to entrepreneurial behavior, organizational innovation also affects organizational performance. The research results of Suryo (2010) and Sartika (2015) proved that organizational innovation influences organizational performance. MSMEs innovate on products, processes, and procedures as well as improve the qualifications of their employees who have adequate knowledge with the technology used, good skills and communication so that they are responsive to macroeconomic changes, process technology changes and market tastes that continue to occur, also, they can always be anticipatory if led by a visionary leader who is able to encourage employees to always develop themselves to be in harmony with the demands of their work.

\subsection{Research Problem}

a) Do entrepreneurial behavior and organizational innovation partially affect organizational performance?

b) Do entrepreneurial behavior and organizational innovation simultaneously affect organizational performance?

\subsection{Research Purpose}

This study aims to analyze the simultaneously or partially effect of entrepreneurial behavior and organizational innovation on MSMEs Organizational Performance in Lumajang.

\section{THEORETICAL FRAMEWORK AND HYPOTHESES DEVELOPMENT}

\subsection{Entrepreneurial Behavior}

Entrepreneurship is a process of applying creativity and innovation in solving problems and finding opportunities to improve life (Zimmerer, Scarborough, \& Wilson, 2008). Robbins (2003) added that entrepreneurship is a process to pursue opportunities to meet needs and wants through innovation. Borg \& Meredith (1983) defined entrepreneurial behavior as the behavior of people who can see and assess business opportunities, gather the resources needed to take advantage and take appropriate actions to ensure success. Entrepreneurial behavior is very important in entrepreneurship. Someone who has an entrepreneurial mindset will take various actions related to entrepreneurship passionately (Septiana, Kantun, \& Sedyati, 2017). Rante (2011), Iskandar (2017), Ekaputri, Sudarwanto, \& Marlena (2018) concluded that there is a positive relationship between entrepreneurial behavior and business performance.

\subsection{Organizational Innovation}

Organizational innovation is a solution to real problems faced every day. The process that requires everyone, without exception, to participate (Widjajanti, 2014). The concept of innovation in organizations has a long history and different understanding, especially based on competition and the company's strategy in competing. In general, innovation is defined as a way of organization to improve its competitiveness. Many indicators show that the lack of innovation can cause an organization to lag behind the competition or even go out of business. The term innovation was first used by Schumpeter in 1934, as a creation, implementation, and new combination. New combinations can refer to new products, services, work processes, markets, policies, and systems. 
According to Schumpeter, innovation consists of introducing new products, introducing new processes, opening new markets, developing new sources of supply for raw materials or other inputs and changes in industrial organizations.

According to Schumann (1994), innovation is the way an organization implements new ideas and creative concepts as a basis for competitive advantage in anticipating and fulfilling consumer needs. According to Chen \& Huang (2008), innovation is related to the introduction of new combinations of essential production factors into the production system. Innovation is a terminology to explain how an organization creates value by developing new knowledge and using existing knowledge in new ways. Furthermore, Tan \& Nasurdin (2011) defined organizational innovation as the ability to create new ideas or concept and to create new behaviors for organizations; this consists of innovation in products, innovation in processes and innovation in administration (procedures). Innovation Management is the management of all processes of innovation, research and development, in the broad sense, R \& D management can be interpreted as innovation management when it comes to invention processes and innovation processes.

According to Schumann (1994), innovation can be seen from two dimensions; they are the nature and how much change is made. The dimension of nature can be classified into three categories:

a) Product innovation is all that relates to functions that can be given to customers (internal and external) or forms that function. Product Innovation involves the way things interact with things.

b) Process innovation is anything that involves the way a product is developed, produced, and prepared, for example, improving the manufacturing process and distribution system. Innovation Process involves the interaction of people with things.

c) Innovation procedures are anything that involves any way in which products and processes are integrated into the operations of an organization - for example, improvement marketing methods and administrative methods. Procedure Innovation involves the way people interact with people.

The results of the research by Mustikowati \& Tysari (2014) states that innovation influences the performance of the company. The results of this study are in line with Sartika (2015), which stated that innovation influences organizational performance.

\subsection{Organizational Performance}

Organizational performance is the level of achievement of the organization in carrying out its activities in a certain period (usually in one year). Performance is a reflection of whether the organization or company has succeeded or not in its business venture (Triatmanto, 2011). Performance is a process used by leaders to determine whether an employee does the work according to his/her duties and responsibilities or not so that the steps used to represent performance are chosen based on the state of the organization being observed (Puryantini, Arfati, \& Tjahjadi, 2017). Performance is a description of the success or failure of the organization in carrying out its main duties and functions to realize the goals, objectives, vision, and mission. In other words, performance is an achievement that can be achieved by an organization in a certain period. Organizational performance is important according to Robbins \& Coulter (2005) because it will produce good asset management (tangible assets and intangible assets), increase the ability to provide customer value, create a good company reputation, and improve the size of organizational knowledge. Companies need to carry out performance evaluations that focus on inadequate employee skills and potential so that they can be developed and improved to achieve high organizational performance. 
Based on the three conceptual frameworks described, it can be concluded that the hypotheses in this study are:

$\mathrm{H}_{1}$ : Entrepreneurial behavior and organizational innovation simultaneously affect organizational performance.

$\mathrm{H}_{2}$ : Entrepreneurial behavior and organizational innovation partially affect organizational performance.

\section{RESEARCH METHOD}

\subsection{Research Design}

This study classified as quantitative research due to the aim of the research is to investigate the effect of entrepreneurial behavior and organizational innovation on MSME Organizational Performance in Lumajang was obtained by using a survey method, by using a questionnaire as the main instrument with Likert scale. The data analysis technique used in the study was multiple linear regression analysis. The following equation can be seen below:

$\mathrm{Y}=\mathrm{a}+\mathrm{b}_{1} \mathrm{X}_{1}+\mathrm{b}_{2} \mathrm{X}_{2}+\mathrm{e}$

Description:

$\mathrm{Y}=$ Organization Performance

$\mathrm{a}=$ Constant

$\mathrm{b}_{1,2}=$ Coefficient

$\mathrm{X}_{1}=$ Entrepreneurial Behavior

$\mathrm{X}_{2}=$ Organizational Innovation

Table 1 Variable and Indicator

\begin{tabular}{|c|l|l|l|}
\hline No & \multicolumn{1}{|c|}{ Variable } & \multicolumn{1}{|c|}{ Definition } & \multicolumn{1}{|c|}{ Indicator } \\
\hline 1 & $\begin{array}{l}\text { Entrepreneur } \\
\text { Behavior } \\
\text { Borg } \\
\text { Meredith, } \\
1983)\end{array}$ & $\begin{array}{l}\text { The behavior of people who can see } \\
\text { and assess business opportunities, } \\
\text { gather the resources needed to take } \\
\text { advantage and take appropriate actions } \\
\text { to ensure success. }\end{array}$ & $\begin{array}{l}\text { Confidence, task and result } \\
\text { oriented, risk taker, leadership, } \\
\text { originality, and visionary. }\end{array}$ \\
\hline 2 & $\begin{array}{l}\text { Organizational } \\
\text { Innovation } \\
\text { Schumann, } \\
1994)\end{array}$ & $\begin{array}{l}\text { The way an organization implements } \\
\text { new ideas and creative concepts as a } \\
\text { basis for competitive advantage in } \\
\text { anticipating and fulfilling consumer } \\
\text { needs. }\end{array}$ & $\begin{array}{l}\text { Product innovation, process } \\
\text { innovation, and procedure } \\
\text { innovation }\end{array}$ \\
\hline 3 & $\begin{array}{l}\text { Organizational } \\
\text { Performance } \\
\text { Triatmanto, } \\
\text { 2011) }\end{array}$ & $\begin{array}{l}\text { reflection of whether the } \\
\text { organization or company has } \\
\text { succeeded or not in its business } \\
\text { venture. }\end{array}$ & $\begin{array}{l}\text { Financial performance and } \\
\text { Marketing Performance }\end{array}$ \\
\hline
\end{tabular}

\subsection{Population and Sample}

The population was the MSME entrepreneurs in Lumajang who have SIUP (business permit from the government) which is amounted to 196. The reason in choosing Lumajang as research object is because there are many MSME in Lumajang that not operating in an effective and efficient way. According to Arikunto (2010) for the population that higher than 100 respondent, the sample 
size should amount $10-20 \%$ from the total population. Therefore, the number of samples in the study was 39.2 (or 40 MSMEs). The sampling technique used in this research was simple random sampling.

\subsection{Research Framework}

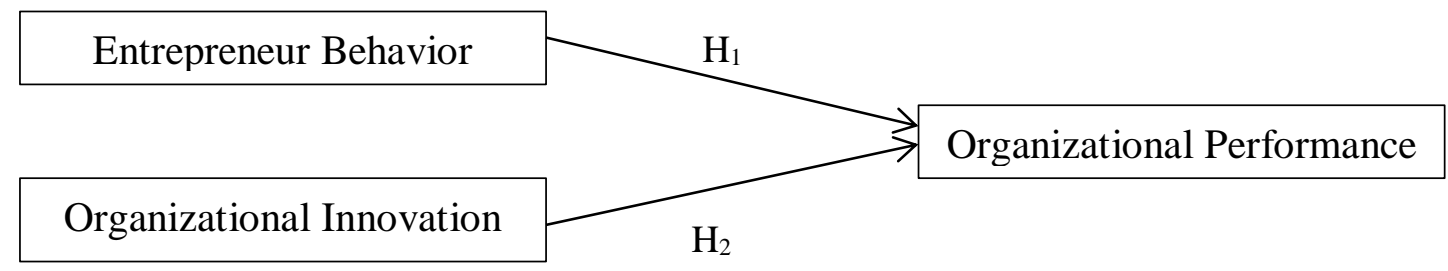

Picture 1 Research Framework

\section{RESEARCH RESULT AND ANALYSIS}

\subsection{Descriptive Analysis}

Characteristics of respondents in the study are presented in the following table.

Table 2 Characteristics of Respondents

\begin{tabular}{|l|c|c|}
\hline \multicolumn{1}{|c|}{ Category } & Frequency & Percentage (\%) \\
\hline Age & 8 & 20,0 \\
\hline $20-30$ years old & 13 & 32,5 \\
\hline $31-40$ years old & 19 & 47,5 \\
\hline $40-50$ years old & & \\
\hline Sex & 28 & 70,0 \\
\hline Male & 12 & 30,0 \\
\hline Female & & \\
\hline Business Ages & 7 & 17,5 \\
\hline $1-5$ years & 16 & 40,0 \\
\hline $5,1-10$ years & 17 & 42,5 \\
\hline More than 10 years & 2019 \\
\hline
\end{tabular}

Source: Primary Data Processed, 2019

Based on Table 2, it can be seen that the majority category in this study is 40 - 50 years old with 19 respondents $(47, \%)$, male with 28 respondents $(70 \%)$ and have a duration of business more than 10 years with 17 respondents $(42,5 \%)$.

\subsection{Validity and Reliability}

Measuring the validity of this instrument was done by Pearson Product Moment correlation between the scores of the items with the scale score. Overall, the results of testing the validity of each variable are presented in the following table. 
JEMA: Jurnal Ilmiah Bidang Akuntansi dan Manajemen, Vol. 16 No. 2 (2019)

http://riset.unisma.ac.id/index.php/jema (e-ISSN : 2597-4071)

Table 3 Validity Result

\begin{tabular}{|c|c|c|c|c|c|c|}
\hline Variable & Indicator & Item & r-value & r critical & Probabilty & Description \\
\hline \multirow{12}{*}{$\begin{array}{l}\text { Entrepreneurial } \\
\text { behavior }\end{array}$} & \multirow{2}{*}{ Confidence } & X1.1.1 & 0,603 & 0,312 & 0,000 & Valid \\
\hline & & $\mathrm{X} 1.1 .2$ & 0,823 & 0,312 & 0,000 & Valid \\
\hline & \multirow{2}{*}{$\begin{array}{l}\text { Task and result } \\
\text { oriented }\end{array}$} & $\mathrm{X} 1.2 .1$ & 0,728 & 0,312 & 0,000 & Valid \\
\hline & & $\mathrm{X} 1.2 .2$ & 0,818 & 0,312 & 0,000 & Valid \\
\hline & \multirow{2}{*}{ Risk taker } & $\mathrm{X} 1.3 .1$ & 0,735 & 0,312 & 0,000 & Valid \\
\hline & & X1.3.2 & 0,759 & 0,312 & 0,000 & Valid \\
\hline & \multirow{2}{*}{ Leadership } & $\mathrm{X} 1.4 .1$ & 0,707 & 0,312 & 0,000 & Valid \\
\hline & & $\mathrm{X} 1.4 .2$ & 0,776 & 0,312 & 0,000 & Valid \\
\hline & \multirow{2}{*}{ Originality } & $\mathrm{X} 1.5 .1$ & 0,823 & 0,312 & 0,000 & Valid \\
\hline & & $\mathrm{X} 1.5 .2$ & 0,745 & 0,312 & 0,000 & Valid \\
\hline & \multirow{2}{*}{ Visionary } & X1.6.1 & 0,617 & 0,312 & 0,000 & Valid \\
\hline & & $\mathrm{X} 1.6 .2$ & 0,749 & 0,312 & 0,000 & Valid \\
\hline \multirow{6}{*}{$\begin{array}{l}\text { Organizational } \\
\text { Innovation }\end{array}$} & \multirow{2}{*}{$\begin{array}{l}\text { Product } \\
\text { innovation }\end{array}$} & $\mathrm{X} 2.1 .1$ & 0,770 & 0,312 & 0,000 & Valid \\
\hline & & $\mathrm{X} 2.1 .2$ & 0,690 & 0,312 & 0,000 & Valid \\
\hline & \multirow{2}{*}{$\begin{array}{l}\text { Process } \\
\text { innovation }\end{array}$} & $\mathrm{X} 2.2 .1$ & 0,612 & 0,312 & 0,000 & Valid \\
\hline & & $\mathrm{X} 2.2 .2$ & 0,473 & 0,312 & 0,002 & Valid \\
\hline & \multirow{2}{*}{$\begin{array}{l}\text { Procedure } \\
\text { innovation }\end{array}$} & $\mathrm{X} 2.3 .1$ & 0,573 & 0,312 & 0,000 & Valid \\
\hline & & $\mathrm{X} 2.3 .2$ & 0,675 & 0,312 & 0,000 & Valid \\
\hline \multirow{4}{*}{$\begin{array}{l}\text { Organizational } \\
\text { Performance }\end{array}$} & \multirow{2}{*}{$\begin{array}{c}\text { Financial } \\
\text { performance }\end{array}$} & Y1.1.1 & 0,560 & 0,312 & 0,000 & Valid \\
\hline & & $\mathrm{Y} 1.1 .2$ & 0,755 & 0,312 & 0,000 & Valid \\
\hline & \multirow{2}{*}{$\begin{array}{c}\text { Marketing } \\
\text { performance }\end{array}$} & Y1.2.1 & 0,533 & 0,312 & 0,000 & Valid \\
\hline & & Y1.2.2 & 0,804 & 0,312 & 0,000 & Valid \\
\hline
\end{tabular}

Source: Primary Data Processed, 2019

Table 3 shows that all of the questionnaire item has coefficient $r$ value greater than $r$ critical and probability value smaller than $\alpha=5 \%$, it means that the instruments used are valid and can be used to measure variables of entrepreneurial behavior, organizational innovation, and organizational performance.

Table 4 Reliability Result

\begin{tabular}{|l|c|c|}
\hline \multicolumn{1}{|c|}{ Variable } & Alpha Cronbach & Description \\
\hline Entrepreneurial Behavior & 0,924 & Reliable \\
\hline Organizational Innovation & 0,701 & Reliable \\
\hline Organizational Performance & 0,690 & Reliable \\
\hline
\end{tabular}

Source: Primary Data Processed, 2019

The reliability test results presented in Table 4 shows that each reliability coefficient value was greater than 0,6 so that the instruments used have a high chance of being answered consistently by the respondents. 


\subsection{Research Analysis}

In order to obtain an unbiased and efficient estimator value from a multiple regression equation, the data analysis must fulfill the following classic assumptions:

a. Multicollinearity

A regression model is free from multicollinearity if the VIF (Variance Inflation Factors) value of each independent variable is less than 10 , and the tolerance value is more than 0,10 .

Table 5 Multicollinearity Test Results

\begin{tabular}{|l|c|c|}
\hline \multirow{2}{*}{ Variable } & \multicolumn{2}{c|}{ Collinearity Statistics } \\
\cline { 2 - 3 } & Tolerance & VIF \\
\hline Entrepreneurial Behavior & 0,560 & 1,786 \\
\hline Organizational Innovation & 0,560 & 1,786 \\
\hline
\end{tabular}

Source: Primary Data Processed, 2019

Based on the VIF calculation results, it can be seen that the variables of entrepreneurial behavior, organizational innovation, and organizational competence have a VIF value $<10$ and tolerance $>$ 0,10 , thus it can be concluded that the regression model does not have a multicollinearity problem.

b. Autocorrelation

To determine the presence or absence of autocorrelation symptoms in the regression analysis model used was by testing the serial correlation model with the Durbin-Watson (DW) method. Conventionally it can be said that a regression equation is said to have fulfilled the assumption that there is no autocorrelation if the value of the Durbin-Watson test is between the dU and (4-dU). The $\mathrm{dU}$ value in the Durbin-Watson table is 1,60 . Based on the calculation results, it can be seen that the value of the Durbin-Watson test is 1,712 so that it is greater than 1,60 (dU) and smaller than 2,40 (4-dU). It means there is no autocorrelation in the regression model.

c. Heteroscedasticity

Heteroscedasticity means that there are unequal residual variations for all observations, or there is a presence of greater residual variations in the number of observations that are getting bigger. Testing for symptoms of heteroscedasticity was using the Park test as presented in the following table.

Table 6 Park Test Result

\begin{tabular}{|l|c|c|}
\hline Model & $\mathrm{t}$ & Sig. \\
\hline (Constant) &, 491 & 0,626 \\
\hline Ln Entrepreneurial Behavior & $-1,427$ & 0,162 \\
\hline Ln Organizational Innovation & 1,159 & 0,254 \\
\hline
\end{tabular}

Source: Primary Data Processed, 2019

Based on the table above, the $t$ value of the variable entrepreneurial behavior ( $\mathrm{LnX} 1)$ is $-1,427$ which is smaller than the t table value of 2,021 , or the significance value is 0,162 , which is greater than $\alpha=0,05$, and the value of the calculated variable t-test of organizational innovation (LnX2) is 1,159 , which is smaller than $t$ table value of 2,021 , or the significance value is 0,254 , which is greater than $\alpha=0,05$. Thus there are no symptoms of heteroscedasticity.

d. Normality

Data assumption has been normally distributed is one of the important assumptions in conducting research with regression. This test aimed to test whether, in the regression model, the independent and dependent variables are normally distributed or not. The results of the normality 
test were obtained through the Kolmogorov Smirnov Test (KST) calculation presented in the following table.

Table 7 One K-S Results

\begin{tabular}{|l|c|c|c|}
\hline \multicolumn{1}{|c|}{ Description } & $\begin{array}{c}\text { Entrepreneurial } \\
\text { Behavior }\end{array}$ & $\begin{array}{c}\text { Organizational } \\
\text { Innovation }\end{array}$ & $\begin{array}{c}\text { Organizational } \\
\text { Performance }\end{array}$ \\
\hline $\mathrm{N}$ & 40 & 40 & 40 \\
\hline Kolmogorov-Smirnov Z & 0,886 & 0,895 & 0,842 \\
\hline Asymp. Sig. (2-tailed) & 0,441 & 0,407 & 0,478 \\
\hline
\end{tabular}

Source: Primary Data Processed, 2019

Based on the results of the Kolmogorov Smirnov Test (KST), the significance asymp value of entrepreneurial behavior, organizational innovation, and organizational performance variable are $0.866,0,895,0,842$ with a significance value of $0,441,0,407,0,478$ which is greater than the standardized significant value of 0,05 . This shows that the variables of entrepreneurial behavior, organizational innovation, and organizational performance are normally distributed.

\subsection{Research Discussion}

Table 8 Multiple Linear Regression Result

\begin{tabular}{|c|c|c|c|c|c|}
\hline & Variable & $\begin{array}{l}\text { Regression } \\
\text { Coefficient }\end{array}$ & $t_{\text {-test }}$ & Sig. & Description \\
\hline Entrepren & ial Behavior $\left(\mathrm{X}_{1}\right)$ & 0,414 & 4,094 & 0,000 & Significant \\
\hline Organizati & al Innovation $\left(\mathrm{X}_{2}\right)$ & 0,651 & 5,911 & 0,000 & Significant \\
\hline Constant & 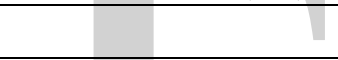 & \multicolumn{4}{|c|}{$-0,209$} \\
\hline $\mathrm{R}$ & & \multicolumn{4}{|c|}{0,895} \\
\hline R square & & \multicolumn{4}{|c|}{0,802} \\
\hline \multicolumn{2}{|c|}{ Adjusted R Square } & \multicolumn{4}{|c|}{0,791} \\
\hline \multicolumn{2}{|l|}{$\mathrm{F}_{\text {-test }}$} & \multicolumn{4}{|c|}{74,847} \\
\hline \multicolumn{2}{|l|}{ Sig. F } & \multicolumn{4}{|c|}{0,000} \\
\hline \multicolumn{2}{|l|}{$\mathrm{N}$} & \multicolumn{4}{|c|}{40} \\
\hline \multicolumn{2}{|l|}{ F table } & \multicolumn{4}{|c|}{3,26} \\
\hline \multicolumn{2}{|l|}{ t table } & \multicolumn{4}{|c|}{2,021} \\
\hline \multicolumn{2}{|c|}{ Dependent variable } & \multicolumn{4}{|c|}{ Organizational Performance (Y) } \\
\hline
\end{tabular}

Source: Primary Data Processed, 2019

From the results of the multiple regression calculation above, it can be seen that the value of the determination coefficient ( $\mathrm{R}$ square) is 0,802 . This means that entrepreneurial behavior $\left(\mathrm{X}_{1}\right)$ and organizational innovation $\left(\mathrm{X}_{2}\right)$ can simultaneously contribute to organizational performance by $80.2 \%$, while the remaining $19,8 \%$ is caused by other variables not included in this study. Meanwhile, the results of the hypothesis test in this study can be seen as follows:

a) $\mathrm{H}_{1}$ Testing

To test the first hypothesis which states that entrepreneurial behavior and organizational innovation simultaneously affect organizational performance was to use the F test. The results of the calculation of multiple regression analysis with SPSS obtained F-test of 74,847, $F_{\text {table }}$ on $\alpha=$ $5 \%, \mathrm{df}_{1}=3$, and $\mathrm{df}_{2}=37$ of 3,26 ; it means $\mathrm{F}_{\text {test }}>\mathrm{F}_{\text {table }}(74,847>3,26)$ while the probability value is 
smaller than $\alpha=0,05(0,000<0,05)$, then Ho is rejected and Ha is accepted, which means that the independent variable: Entrepreneurial behavior and organizational innovation simultaneously have a significant effect on organizational performance. Thus the first hypothesis is statistically tested.

b) $\mathrm{H}_{2}$ Testing

To test the second hypothesis which states entrepreneurial behavior and organizational innovation partially affect the performance of the organization was by using the t-test. T-test is used to test whether each independent variables of Entrepreneurial behavior and organizational innovation partially have a significant effect on organizational performance, by comparing between $\mathrm{t}$-test with $\mathrm{t}$-table. The each $\mathrm{t}$-test dan $\mathrm{t}_{\text {-table }}$ value of the independent variable is as follows:

Table 9 Comparison of t-test and $t_{\text {table }} \alpha=5 \%$

\begin{tabular}{|l|c|c|c|c|}
\hline \multicolumn{1}{|c|}{ Variable } & $\mathrm{t}_{\text {-test }}$ & $\mathbf{t}_{\text {-table }}$ & Sig. & Description \\
\hline Entrepreneurial behavior $\left(\mathrm{X}_{1}\right)$ & 4,094 & 2,021 & 0,000 & Significant \\
\hline Organizational innovation $\left(\mathrm{X}_{2}\right)$ & 5,911 & 2,021 & 0,000 & Significant \\
\hline
\end{tabular}

Source: Primary Data Processed, 2019

The results of the Entrepreneurial behavior regression analysis obtained a value of t-test $=4,094$ while the value of $t_{\text {table }}=2,021$ so that $\mathrm{t}$-test $>\mathrm{t}_{\text {table }}$ or significance value $0,000<0,05$ so Ho is rejected or $\mathrm{Ha}$ is accepted, and it is proven that entrepreneurial behavior variable $\left(\mathrm{X}_{1}\right)$ has a significant effect on organizational performance $(Y)$. Meanwhile, the results of the Organizational innovation regression analysis obtained the value of $\mathrm{t}$-test $=5.911$ while the value of $\mathrm{t}_{\text {-table }}=2,021$ so that $\mathrm{t}$-test $>\mathrm{t}_{\text {-table }}$ or significance value $0,000<0,05$ so Ho is rejected or $\mathrm{Ha}$ is accepted, and it is proven that organizational innovation variable $\left(\mathrm{X}_{2}\right)$ has a significant effect on organizational performance . Therefore, based on the results of the t-test, it can be proven that entrepreneurial behavior and organizational innovation partially have a significant effect on organizational performance. Thus the second hypothesis is statistically accepted.

\subsubsection{The Effect of Entrepreneurial Behavior and Organizational Innovation on Organizational Performance}

Entrepreneurial behavior and organizational innovation simultaneously affect organizational performance. This shows that better entrepreneurial behavior and supported by organizational innovation can improve organizational performance. Entrepreneurial behavior is formed by selfconfidence, task and results-oriented, risk takers, leadership, originality and future-oriented, with the greatest contribution to leadership reflected in the work environment being able to get along with others. This is in accordance with the finding by Borg \& Meredith (1983) which stated that entrepreneurial behavior is the behavior of people who have the ability to see and assess business opportunities, gather the resources needed to take advantage and take appropriate actions to ensure success. Organizational innovation is formed from product innovation, process innovation, and procedure innovation. The biggest contribution to the formation of organizational innovation is process innovation reflected by improving quality in the process. In operational activities, companies must be able to simplify the work process in order to obtain efficiency or make a completely new process by leaving the old operating process or make the improvement of existing processes in achieving the work results of the organization. Process innovations include significant implementations in productions and delivery methods, including techniques, tools, and software. According to Tan \& Nasurdin (2011), organizational innovation is the ability to create new ideas or concept and to create new behaviors for organizations; this consists of innovation in products, innovation in processes and innovation in administration (procedures). UMKM practitioners who 
have high entrepreneurial and innovative behavior are one of the keys to entrepreneurship. Every person is equipped with talent or entrepreneurial spirit in varying degrees of capability. If the entrepreneurial spirit or talent have a good platform, the development and progress will produce the expected results. This is supported by respondents who were mostly 40-50 years old, male and have had more than ten years of business, so that they can produce high innovative behaviors especially to make the best decisions that have an impact on improving organizational performance.

\subsubsection{The Effect of Entrepreneurial Behavior on Organizational Performance}

Entrepreneurial behavior has a significant effect on organizational performance. Entrepreneurial behavior described by the originality in which reflected in work performed in accordance with the experience, meaning that it is done creatively, innovatively, and flexible, with great knowledge, so that it can improve the performance, which is shown in financially where the managed MSMEs were experiencing increased business profits. To win the competition, an entrepreneur must have high creativity. The creative power should be based on advanced thinking, full of new ideas that are different from the products that have been available in the market. Creative ideas generally cannot be limited by space, form, or time. It is often the genius ideas that provide breakthroughs in the initial business world based on creative ideas that seem impossible. However, good ideas, if not implemented in everyday life, will only become a dream.

Genius ideas generally require high innovation power from the entrepreneur concerned. High creativity still requires a touch of innovation to sell well in the market. The innovation needed is the ability of entrepreneurs to add use value/benefit to a product and maintain product quality by paying attention to "market-oriented" or what is being sold in the market. With the increase in the use value or benefits of a product, the selling power of the product increases in the eyes of consumers because there is an increase in economic value for the product for consumers. The results of this study are consistent with the research conducted and Rajabi, Brashear-Alejandro, \& Chelariu (2018), which stated that entrepreneurial behavior affects performance. The results of this study also support Rante (2011) that entrepreneurial behavior affects business performance. Iskandar (2017) found that entrepreneurship affects business performance. Furthermore, the results of the study by Ekaputri, Sudarwanto, \& Marlena (2018) found that entrepreneurial behavior affects company performance. However, the results of Adinoto (2010) stated that entrepreneurial behavior does not affect performance.

\subsubsection{The Effect of Organizational Innovation on Organizational Performance}

Organizational innovation has a significant effect on organizational performance. Organizational innovation is an effort to maintain the existence of the organization and improve organizational progress. With organizational innovation, an organization is expected to be able to respond to the complexity of the environment and the dynamics of changes in the environment, especially in the cut-throat competition and to create sources for competitive advantage. This can be achieved through product innovation, process innovation, and procedure innovation. According to Tan \& Nasurdin (2011), organizational innovation is the ability to create new ideas or concept and to create new behaviors for organizations, this consists of innovation in products, innovation in processes and innovation in administration (procedures). The product innovation can be realized from new product innovations with the technically different specifications and functions from those already available; the renewal of the product leads to improved customer use and satisfaction; product development now uses different components and materials than before; there is a decrease in the production costs, components, and materials of the current product and there is an increase in the quality of production in terms of the components and materials of the product. Process 
innovation can be realized by reducing the activities of distribution that do not have added value for the company, reducing variable costs and increasing the speed of delivery in terms of logistics processes, reducing process steps so that production costs become lower, it is important for companies to choose the right location to get low-cost production factors locally and globally, and to optimize the energy so that the production process is at the highest efficiency. Procedural innovations can be realized in the improvement of the administration system, so the procedures to be faster and more efficient, a decrease in the intensity of interaction between a person and another person to make the administration process run faster, new distribution channels are made, so that product delivery to markets become faster without reducing quality, new marketing policy is also created to make administrative requirements to be easier and faster with openness/transparency. It will encourage employees to work better in the administration/work of the company. The indicator of organizational innovation that most influences organizational performance is procedure innovation. Procedure Innovation involves how products and processes are integrated into the operations of an organization. The better the application of organizational investment can improve organizational performance in terms of marketing performance and financial performance. The results of this study support the research result by Suryo (2010) and Sartika (2015), which stated that organizational innovation affects organizational performance. The results of this study also support Mustikowati \& Tysari (20114) who found that innovation affects company performance. The results of this study are also in line with Sartika (2015) who stated that innovation affects organizational performance.

\section{RESEARCH CONCLUSION AND LIMITATION}

\subsection{Conclusion}

The results of the analysis showed that entrepreneurial behavior and organizational innovation affect organizational performance, which means that the better entrepreneurial behavior supported by organizational innovation can improve organizational performance. Entrepreneurial behavior partially affects organizational performance, which means that an entrepreneur who has entrepreneurial behavior believes that planning, organizing, mobilizing, and controlling and supported by creativity, innovation, and risk-taking can improve organizational performance. Organizational innovation partially affects organizational performance and is a variable that has a greater impact to organizational performance, which means that MSMEs capable of innovating in terms of product innovation, process innovation, and procedure innovation can improve organizational performance.

\subsection{Limitation}

The conception of organizational performance that are affected by entrepreneurial behavior and organizational innovation still requires a broader study both in the subject and the object to be accepted as the standard model.

\section{REFERENCES}

Adinoto, A. (2010). Pengaruh Orientasi Pasar dan Perilaku Kewirausahaan Terhadap Kepekaan Perusahaan Dan Implikasinya Pada Kinerja Perusahaan: Studi pada Penyalur Sepeda Motor di Indonesia. ULTIMA Management, 2(1), 1-25. https://doi.org/10.31937/manajemen.v2i1.166.

Arikunto, S. (2010). Research procedure a practical approach. Jakarta: PT Rineka Reserved.

Chen, C. J., \& Huang, J. W. (2009). Strategic human resource practices and innovation 
performance-The mediating role of knowledge management capacity. Journal of business research, 62(1), 104-114. https://doi.org/10.1016/j.jbusres.2007.11.016.

Ekaputri, S., Sudarwanto, T., \& Marlena, N. (2018). PERAN LINGKUNGAN INDUSTRI, PERILAKU KEWIRAUSAHAAN, DAN KEMAMPUAN MANAJERIAL TERHADAP KINERJA PERUSAHAAN PADA USAHA LOGAM SKALA MIKRO. JRMSI-Jurnal Riset Manajemen Sains Indonesia, 9(1), 1-21. https://doi.org/10.21009/JRMSI.009.1.01.

Fadiati, A. (2011). Jasa Boga Yang Sukses. Bandung: PT Remaja Rosdakarya.

Iskandar, I. (2017). Pengaruh Kewirausahaan dan Peluang Pasar terhadap Kinerja Usaha Perdagangan Mikro Kecil dan Menengah di Kecamatan Peureulak Kota Kabupaten Aceh Timur. Jurnal Samudra Ekonomi dan Bisnis, 8(1), 611-618. https://doi.org/10.33059/jseb.v8i1.200.

Borg, W. R., \& Meredith D. G. (1983). Educational Research. New York: Longman Inc.

Mustikowati, R. I., \& Tysari, I. (2014). Orientasi Kewirausahaan, Inovasi, Dan Strategi Bisnis Untuk Meningkatkan Kinerja Perusahaan (Studi Pada UKM Sentra Kabupaten Malang). Jurnal Ekonomi Modernisasi, 10(1), 23-37. https://doi.org/10.21067/jem.v10i1.771.

Puryantini, N., Arfati, R., \& Tjahjadi, B. (2017). Pengaruh Knowledge Management Terhadap Kinerja Organisasi Dimediasi Inovasi di Organisasi Penelitian Pemerintah. Berkala Akuntansi dan Keuangan Indonesia, 2(2). http://dx.doi.org/10.20473/baki.v2i2.5325.

Rajabi, R., Brashear-Alejandro, T., \& Chelariu, C. (2018). Entrepreneurial motivation as a key salesperson competence: trait antecedents and performance consequences. Journal of Business \& Industrial Marketing, 33(4), 405-416. https://doi.org/10.1108/JBIM-12-20160278 .

Rante, Y. (2011). Pengaruh budaya etnis dan perilaku kewirausahaan terhadap kinerja usaha mikro kecil agribisnis di Provinsi Papua. Jurnal Manajemen dan Kewirausahaan, 12(2), 133-141. https://doi.org/10.9744/jmk.12.2.pp.\%20133-141.

Robbins, S. P. (2003). Essentials of Organizational Behaviour. New Jersey: Pearson Education.

Robbins, S. P., \& Coulter, M. (2005). Management. 8th Edition. New Jersey: Prentice Hall

Sartika, D. (2015). Inovasi Organisasi Dan Kinerja Organisasi: Studi Kasus Pada Pusat Kajian Dan Pendidikan Dan Pelatihan Aparatur III Lembaga Administrasi Negara. Jurnal Borneo Administrator, 11(2). https://doi.org/10.24258/jba.v11i2.196.

Schumann, P. (1994). Innovate! Straight path to quality, customer delight, and competitive andvantage. New York: McGraw-Hill.

Septiana, A. P., Kantun, S., \& Sedyati, R. N. (2017). PERILAKU KEWIRAUSAHAAN PENGUSAHA MEBEL DI DESA SUCO KECAMATAN MUMBULSARI KABUPATEN JEMBER. JURNAL PENDIDIKAN EKONOMI. Jurnal Ilmiah Ilmu Pendidikan, Ilmu Ekonomi dan Ilmu Sosial, 11(1), 30-38. https://doi.org/10.19184/jpe.v11i1.4994.

Sumantri, S. (2001). Perilaku Organisasi. Bandung: Universitas Padjadjaran.

Suryo, B. D. (2010). Pengaruh Gaya Kepemimpinan Transformasional, Budaya Organisasi dan Inovasi terhadap Kinerja (Studi pada Panti Asuhan di Kota Tomohon dan Kabupaten Minahasa). Jurnal aplikasi manajemen, 8(2), 391-404. Retrieved from 
https://jurnaljam.ub.ac.id/index.php/jam/article/view/337.

Tan, C. L., \& Nasurdin, A. M. (2011). Human resource management practices and organizational innovation: assessing the mediating role of knowledge management effectiveness. Electronic journal of knowledge management, 9(2), 155.

Triatmanto, B. (2011). Peningkatan Kinerja Organisasi melalui Pemberdayaan Sumber Daya Manusia, dan Perubahan Organisasi (Studi pada Industri Jasa di Jawa Timur). Jurnal Aplikasi Manajemen, 9(2), 434-443. Retrieved from https://jurnaljam.ub.ac.id/index.php/jam/article/view/236.

Widjajanti, K. (2014). PENGEMBANGAN INOVASI ORGANISASI BERBASIS HUMAN CAPITAL, SHARING KNOWLEDGE DAN PEMBELAJARAN ORGANISASIONAL. Jurnal Ekonomi \& Bisnis, 15(2), 86-101.

Zimmerer, T. W., Scarborough, N. M., \& Wilson, D. (2008). Essentials of entrepreneurship and small business management. Semarang: PT Salemba Empat.

*) Oyong Lisa, Department of Accounting, Gajayana University, Malang, Indonesia (Email: oyonglisa12@yahoo.com)
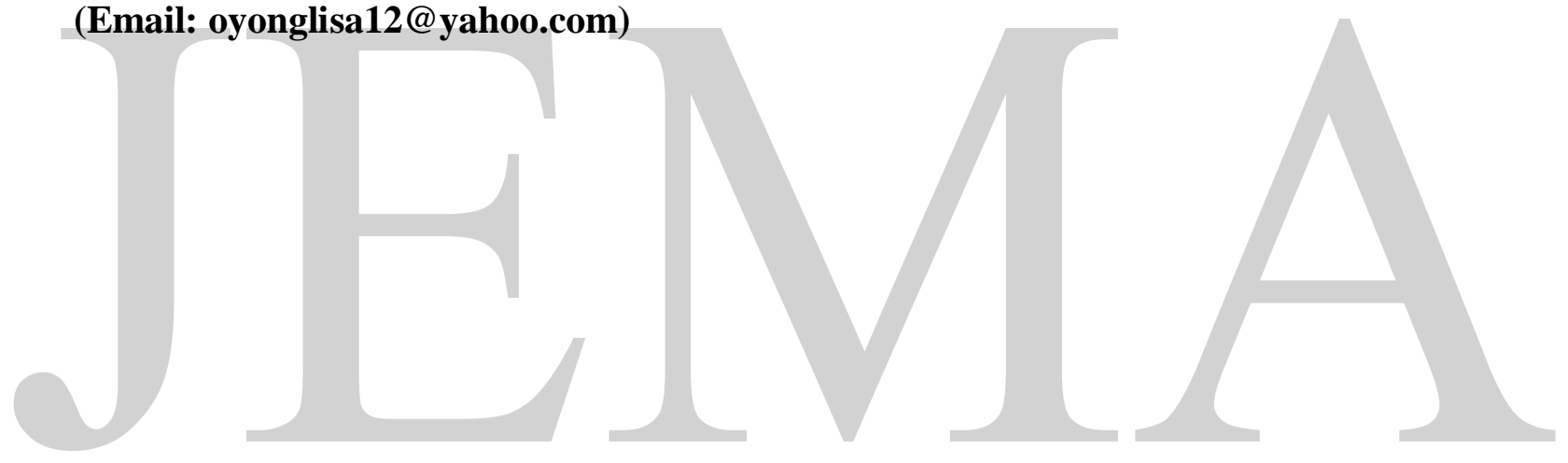